DOCTRINA

\title{
El derecho a no incriminarse y su vinculación con los actos posteriores copenados. Comentarios sobre algunos casos de la jurisprudencia chilena
}

\author{
The right to not self-incriminate and its correlation with subsequent scot-free acts. \\ Comments regarding certain cases of the Chilean jurisprudence
}

\author{
Gloria Mancilla Ibacache \\ Universidad de Talca, Chile
}

\begin{abstract}
RESUMEN Este artículo pretende revisar los lineamientos actuales de la jurisprudencia chilena en relación con el derecho a no incriminarse y a los actos posteriores copenados, para luego abordar los puntos de encuentro entre ambas instituciones. El objetivo es explorar si las respuestas tradicionales de los tribunales superiores, por las cuales se renuncia al castigo de las conductas que realiza un sujeto para encubrir su propio hecho delictivo, son suficientes, o si bien es necesario orientar esta interrogante hacia un horizonte diverso.
\end{abstract}

PALABRAS CLAVE Derecho a no incriminarse, actos posteriores copenados, jurisprudencia chilena, ne bis in idem, nemo tenetur.

ABSTRACT The article attempts to provide a revision of the current guidelines of Chilean jurisprudence regarding the right of not self- incriminate as well as posterior scot- free (concomitant) acts, to subsequently address similarities between both legal concepts. It intends to investigate whether traditional answers by which an individual renounces to the penalty for a crime in favour of concealing his criminal act are enougt, or if is necessary y to direct this interrogation towards a more diverse perspective.

KEYWORDS The right to not self-incrimination, scot-free (concomitant) act, chilean jurisprudence, ne bis in idem, nemo tenetur. 


\section{Introducción}

El derecho a no incriminarse, también denominado como privilegie aginas self- incrimination o nemo tenetur se detegere en la cultura comparada, tiene un tratamiento heterogéneo en los diversos ordenamientos jurídicos alrededor del mundo en que inclusive, con respecto a su estructura, no hay consenso (Trechsel, 2005: 341) y se establece como un principio que limita la búsqueda de la verdad en el proceso (González, 2013: 99). La falta de previsión normativa expresa o, en su defecto, el reconocimiento tácito de este en la legislación a través del debido proceso, y tanto la diferencia de contenido como el significado que cada ordenamiento le otorga a este derecho, genera tensiones en las esferas judiciales y doctrinarias (Ormazábal, 2015: 28 y ss.).

El derecho a no incriminarse tiene una especial importancia en cuanto representa una de las principales limitaciones a la persecución penal (González, 2013: 103), en que más importante que obtener la declaración del imputado o la propia búsqueda de la verdad, prima el obtenerlas con inobservancia de medios opresores como la tortura, apremios o actos que impliquen engaños (Roxin, 2008: 62). ${ }^{1}$ Esta afirmación no es inofensiva para el proceso penal, ya que significa que el imputado no tiene un deber de colaborar produciendo evidencia probatoria (Andrés, 2020: 73) y, por otro lado, que este derecho limitará diversas etapas del proceso penal, desde el interrogatorio hasta la eficacia del examen contradictorio (Andrés, 2020: 93), lo que tendrá consecuencias significativas en sede judicial.

Pese a la falta de uniformidad en su tratamiento, el derecho a no incriminarse se ha constituido como uno de los principios fundamentales en materia internacional reconocido en los procedimientos propios de un Estado de derecho (Roxin, 2008: 59). Este principio constituye un estándar de protección a los derechos del imputado en el proceso penal. La imposibilidad de autoincriminación o de perjudicarse dentro del proceso tiene su fundamento, como se señaló anteriormente, en evitar un sistema inquisitivo de declaración. Así, el no declarar contra sí mismo, no confesarse culpable y el derecho a guardar silencio, se convierten en un mecanismo que refuerza el derecho al debido proceso y un sistema procesal adversarial, que a través de la presunción de inocencia se convertirán en una limitación expresa a la persecución. Este derecho ha tenido una creciente expansión en cuanto elemento de las garantías en el proceso (Ormazábal, 2015: 24).

Según cada ordenamiento, las manifestaciones del derecho a no incriminarse

1. En esta línea, véase Wilenmann (2016: 119), González (2013: 103) y los diversos informes de la Comisión Interamericana de Derechos Humanos. Además, véase Nogueira (2007: 97 y ss.). En relación con engaño, Roxin (2008: 65) señala que los interrogatorios que se obtienen por ardid, aunque sean realizados por la policía, deberían estar prohibidos, con independencia de la gravedad de los hechos, la mayor o menor complejidad de la investigación o de cualquier otra característica adicional del caso. Para complementar, véase Castillo (2012: 437). 
tienen diversa jerarquía. En Estados Unidos, la Quinta Enmienda -incorporada como parte del Bill of Rights- reconoce desde 1791 el derecho a no autoinculparse (Epstein, 2015:30), ${ }^{2}$ entendiendo al privilege against self-incrimination como el privilegio de guardar secreto sobre hechos propios frente a la autoridad en juicios criminales en determinadas circunstancias (Jane, 2010: 21). A través de la Quinta Enmienda, el derecho estadounidense limita la aplicación de este principio solo a las causas criminales frente a determinadas autoridades.

Luego, desde 1966 en adelante, a propósito de la sentencia de la Corte Suprema en el caso Miranda con Arizona, se recurre a la doctrina Miranda para advertir sobre los derechos de los detenidos y el procedimiento que deben tener tanto policías como fiscales en el proceso de detención y posterior interrogatorio. Las advertencias Miranda se enmarcan en la lectura de una serie de derechos que tiene el detenido mientras se encuentra en custodia y siendo interrogado por agentes del Estado (Bilalli-Zendeli, 2015: 160), para proteger al imputado contra la obtención de autoincriminaciones forzadas o, en algún sentido, involuntarias (Castillo, 2012: 434). En la práctica, esta serie de derechos deben ser leídos al imputado para que pueda decidir guardar silencio o prestar declaración con conocimiento absoluto de lo que significa su decisión. En Chile, esta garantía se encuentra contemplada en el artículo 93, letra a), del Código Procesal Penal al señalar que todo imputado tendrá derecho a «que se le informe de manera específica y clara acerca de los hechos que se le imputaren y los derechos que le otorgan la Constitución y las leyes». Esta lectura será relevante cuando el imputado sea llevado ante el juez de garantía, quien está conminado a conocer si a este le informaron sobre sus derechos, ya que la inobservancia de esta lectura - desde una perspectiva estricta- pudiera provocar la ilegalidad de la detención.

La doctrina o precedente Miranda advierte cuatro requisitos en relación con el interrogatorio de quien se encuentra en custodia: i) que la policía le informe sobre el derecho que tiene a guardar silencio; ii) que se le informe sobre la posibilidad de que cualquier parte de su declaración podría ser usada como evidencia probatoria en su contra; iii) que se le informe que tiene derecho de asistencia de un abogado mientras se realiza el interrogatorio; iv) y que tiene derecho a ser representado por un abogado aunque no cuente con los medios económicos para ello (Stein, 2011: 17). En la actualidad, el precedente Miranda no es interpretado de forma amplia, es decir, estas advertencias no son utilizadas a todo evento y, por el contrario, deben cumplir con una serie de requisitos para convocarlas. En relación con esto, Castillo (2012: 435) señala que:

2. Constitución de Estados Unidos, Quinta Enmienda: «ninguna persona será forzada a declarar contra sí misma en ningún juicio criminal». Esta garantía se limita tanto en la Quinta Enmienda como en la tradición británica a las causas criminales. En la misma línea, véase Gray (2013: 548) y Ormazábal (2015: 14). 
Hoy la decisión de Miranda, y las que siguieron, parecen producto de un alambicado conjunto de casos donde permanentemente está en juego la astucia de la policía para intentar violar el mandato de Miranda, y de la Corte que se esfuerza por encontrarles la razón para tornar famélico el derecho a no autoincriminarse.

Como señala el autor, en las sentencias posteriores a Miranda, se ha ido interpretando el derecho a no incriminarse restrictivamente, ${ }^{3}$ además de limitar su aplicación solo a situaciones de detención e interrogatorio con el objeto de evitar medios opresores para obtener declaración.

Para el caso español, el derecho a no incriminarse se instaura como un elemento propio del derecho a la defensa que se reconoce expresamente en la Constitución de 1978 y que pone fin a un proceso dominado por principios inquisitivos para obtener la verdad (Ormazábal, 2015: 214). El derecho a defensa y asistencia de un letrado permiten establecer una estructura de protección para evitar la indefensión de quien se enfrenta a las autoridades. Estos derechos para la tradición española involucran ser informado de la acusación, no declarar contra sí mismo y no confesarse culpable (Lefebvre, 2019: 92). Estas garantías, en definitiva, se convertirán en instrumentales para el derecho a defensa y la presunción de inocencia que tendrán aplicación para los funcionarios que practiquen la detención, la fiscalía y el juez instructor (Lefebvre, 2019: 100). Con todo, al igual que los ordenamientos jurídicos comparados, el derecho español establece límites al ejercicio de este derecho, ${ }^{4} \mathrm{y}$ el Tribunal Constitucional pone un límite en lo que respecta al cumplimiento de «deberes constitucionales» o la protección de bienes jurídicos constitucionalmente relevantes (Pérez y Carrasco, 2018: 396).

La limitación jurisprudencial de la aplicación del derecho que examinamos y que se observa en la jurisprudencia estadounidense es una tendencia que también se aprecia en la lectura de esta garantía por los tribunales de otros sistemas legales. El supuesto de dicha consideración se sustenta, entre otras razones, en los contornos que se le asignan en sus respectivos ordenamientos. Dicha situación se verifica, como ilustraremos, en el acercamiento de la justicia constitucional y de las cortes de apelaciones chilenas frente a ella. Entonces, surge la interrogante de si la interpretación restrictiva de este derecho fundamental puede ser subsanada a través de otras vías de análisis que permitan una consideración más amplia del mismo.

Frente el diagnóstico descrito cabe preguntarse si es posible superar dicha situación a través de algunas vías alternativas. ¿Puede fundarse una posible solución de los actos posteriores copenados en base a la consideración de este derecho? ¿O más bien la solución se podría enmarcar dentro de otras vías de solución? El fundamento final de los casos de actos posteriores copenados es un tema de amplio debate en la

3. En relación con la aplicación restrictiva o absoluta del derecho, véase Trechsel (2005: 344).

4. Al respecto, véase la siguiente jurisprudencia española: STC 110/1984, STC 76/1990; STC 103/1985. 
doctrina comparada y nacional, ya que la solución en la resolución de los casos concretos implica la afectación de importantes garantías individuales. A modo ejemplar, puede señalarse el propio derecho a no incriminarse, el denominado privilegio de autoencubrimiento y el principio ne bis in idem.

Este artículo explora algunos pronunciamientos del Tribunal Constitucional y de los tribunales superiores de justicia chilenos relativos a la vinculación del derecho a no autoincriminarse con estos últimos tópicos y valorar el rendimiento de dichos fallos en pos de una interpretación más amplia de dicha garantía. Sin embargo, no se pretende determinar lineamientos jurisprudenciales generales a partir de los mismos, labor que excede los fines analíticos de esta investigación al exigir una base comparativa de mayor envergadura.

\section{El derecho a no incriminarse en Chile}

Dentro de la doctrina chilena, distintos autores han entregado lineamientos para explicar el derecho a no incriminarse. ${ }^{5}$ Gran parte de ellos responden a una definición amplia del derecho señalando sus elementos o campos de aplicación, como así lo hace la extendida definición de Hernández elaborada al momento de analizar su aplicación en torno a las personas jurídicas, definiéndola como:

El derecho de su titular a no ser obligado de ningún modo a colaborar activamente con la persecución penal en su contra. Comprende, en consecuencia, «el derecho a guardar silencio», el derecho a no ser compelido a manifestar o entregar objetos $y$, en general, el derecho a no ser compelido a realizar ninguna actividad que favorezca la investigación y el eventual castigo de hechos que se le imputan (Hernández, 2015: 218-219).

Esta definición nos parece lo suficientemente amplia para entender que no se realizó atendiendo únicamente a la normativa chilena existente sobre este derecho.

El contenido del derecho a no incriminarse contempla el despliegue de una multiplicidad de acciones, como ya señaló Hernández, pero estas se encuentran determinadas y limitadas por el principio de inocencia y el derecho a guardar silencio (Valenzuela, 2015: 17), además de una regla implícita del artículo 19, número 7 , letra f), de la Constitución Política, ${ }^{6}$ que describe de mejor manera su naturaleza. De esta

5. Para más información, véase Horvitz y López (2004: 79), Wilenmann (2016: 113), Valenzuela (2015: 17), Hernández (2015: 218) y González (2013: 102).

6. Artículo 19: La Constitución asegura a todas las personas: 7) El derecho a la libertad personal y a la seguridad individual. En consecuencia: $f$ ) En las causas criminales no se podrá obligar al imputado o acusado a que declare bajo juramento sobre hecho propio; tampoco podrán ser obligados a declarar en contra de este sus ascendientes, descendientes, cónyuge y demás personas que, según los casos y circunstancias, señale la ley. 
forma, González (2013: 102) define esta regla como «aquella que permite al imputado negarse a responder ciertas preguntas cuya respuesta pueda implicar que se le persiga criminalmente por un delito, a él o a algún miembro de su familia o cercano (conviviente, cónyuge, ascendiente o descendiente)».

La jurisprudencia nacional, al tratar el derecho a no incriminarse, tenderá a inclinarse por una definición más restringida como la recién mencionada.?

Existe, para el afectado, una dimensión pasiva que contempla el supuesto de mantener en su competencia el resguardo de sus acciones con la finalidad de no incriminarse. Este es el caso del derecho que le asiste a optar por guardar silencio ante las interrogantes de sus aprehensores ${ }^{8} \mathrm{y}$, por otra parte, la dimensión activa prevé las posibilidades de desplegar una serie de conductas para encubrir el hecho, que de alguna forma provocan una ampliación del reproche como la negación a exhibir documentos o esconder el cadáver. Este tipo de acciones, contempladas en la dimensión activa del derecho, tendrán importante relevancia al momento del castigo penal, ya que el despliegue de conductas - en algunos casos- tendrá un mayor reproche penal que se traducirá en su castigo. Con todo, es necesario señalar que la cuestión de los límites y otros dilemas relacionados con los derechos procesales, ${ }^{9}$ como es el derecho a no incriminarse, responde precisamente a la naturaleza instrumental de ellos (García y Contreras, 2013: 232). ${ }^{10}$

En el ordenamiento jurídico chileno no hay reconocimiento explícito del derecho a no incriminarse, pero sí se encuentran diversas manifestaciones de él, comenzando con un reconocimiento implícito en la Constitución Política en el artículo 19, número 7, letra f), que se traduce en la prohibición de obligar al imputado a declarar contra sí mismo o a sus parientes a declarar en contra de él. Por otra parte, se pueden encontrar elementos relacionados con este derecho en el artículo 19 , número $3{ }^{11}$ que establece

7. Sentencia del Tribunal Constitucional, rol 5952-19; 2381-13; 2936-16; 3948-17; 2897-15.

8. Consideramos que la disposición del artículo 19 , número 7 , letra f) de la Constitución se enmarca dentro de la dimensión pasiva del derecho a no incriminarse.

9. La Corte Interamericana de Derechos Humanos define a los derechos procesales como «el conjunto de requisitos que deben observarse en las instancias procesales». Estas garantías se encuentran en el artículo 8 de la Convención. Para más información, véase Nogueira (2007: 45).

10. Los derechos procesales, según su naturaleza instrumental, están al servicio de bienes jurídicos y derechos fundamentales (García y Contreras, 2013: 232), por lo que se puede entender que dichos derechos son un mecanismo preventivo para la concreción de las demás garantías y bienes jurídicos atendidos por el derecho penal. En términos similares, véase Wilenmann (2016: 112-113).

11. Artículo 19: La Constitución asegura a todas las personas: 3) La igual protección de la ley en el ejercicio de sus derechos. Toda persona tiene derecho a defensa jurídica en la forma que la ley señale y ninguna autoridad o individuo podrá impedir, restringir o perturbar la debida intervención del letrado si hubiere sido requerida. Tratándose de los integrantes de las Fuerzas Armadas y de Orden y Seguridad Pública, este derecho se regirá, en lo concerniente a lo administrativo y disciplinario, por las normas pertinentes de sus respectivos estatutos. La ley arbitrará los medios para otorgar asesoramiento y de- 
diversos mandatos para un debido proceso, pese a que este derecho tampoco tiene un reconocimiento explícito en la Constitución Política (García y Contreras, 2013: 230). ${ }^{12}$

Por último, por la vía del artículo 5, inciso 2, del mismo cuerpo normativo, encontramos el reconocimiento de los tratados internacionales ratificados por Chile con efecto vinculante para nuestros tribunales de justicia. Estos tratados, a diferencia de las leyes nacionales, sí manifiestan un reconocimiento explícito del derecho a no incriminarse.

Los tratados internacionales que reconocen este derecho fundamental son el Pacto Internacional de Derechos Civiles y Políticos en su artículo 14.3, letra g), ${ }^{13}$ que prohíbe que una persona sea obligada a declarar contra sí misma, y la Convención Americana de Derechos Humanos en su artículo 8.2, letra g), que prescribe además del derecho a no declarar contra sí mismo el derecho a no declararse culpable (García y Contreras, 2013: 230). ${ }^{14}$ Estos tratados también reconocen otros derechos fundamentales como la presunción de inocencia, el debido proceso y el derecho a defensa.

El Código Procesal Penal chileno distingue al imputado como un sujeto procesal, dotado de garantías y deberes expresamente señalados en este cuerpo normativo, específicamente en el artículo 93. La letra g) de este artículo señala entre los derechos del imputado «el derecho a guardar silencio o, en caso de consentir en prestar declaración, a no hacerlo bajo juramento, como elemento de defensa» (Correa, 2018: 239).

Sin perjuicio de lo dispuesto en los artículos 91 y 102, al ser informado el imputado del derecho que le asiste conforme a esta letra, con respecto a la primera declaración que preste ante el fiscal o la policía, según el caso, deberá señalársele lo

fensa jurídica a quienes no puedan procurárselos por sí mismos. La ley señalará los casos y establecerá la forma en que las personas naturales víctimas de delitos dispondrán de asesoría y defensa jurídica gratuita, a efecto de ejercer la acción penal reconocida por esta Constitución y las leyes. Toda persona imputada de delito tiene derecho irrenunciable a ser asistida por un abogado defensor proporcionado por el Estado si no nombrare uno en la oportunidad establecida por la ley. Nadie podrá ser juzgado por comisiones especiales, sino por el tribunal que señalare la ley y que se hallare establecido por esta con anterioridad a la perpetración del hecho. Toda sentencia de un órgano que ejerza jurisdicción debe fundarse en un proceso previo legalmente tramitado. Corresponderá al legislador establecer siempre las garantías de un procedimiento y una investigación racional y justa. La ley no podrá presumir de derecho la responsabilidad penal. Ningún delito se castigará con otra pena que la que señale una ley promulgada con anterioridad a su perpetración, a menos que una nueva ley favorezca al afectado. Ninguna ley podrá establecer penas sin que la conducta que se sanciona esté expresamente descrita en ella.

12. Pese a que estas garantías no están indicadas expresa y literalmente en la norma legal, se encuentran en ella todos los elementos para dotarlas de contenido, como lo ha realizado la doctrina y jurisprudencia.

13. Durante el proceso, toda persona acusada de un delito tendrá derecho, en plena igualdad, a no ser obligada a declarar contra sí misma ni a confesarse culpable.

14. Para ver diferencias sobre la manifestación del derecho en cada Convención, véase Trechsel (2005: $340)$. 
siguiente: «Tiene derecho a guardar silencio. El ejercicio de este derecho no le ocasionará ninguna consecuencia legal adversa; sin embargo, si renuncia a él, todo lo que manifieste podrá ser usado en su contra». Este artículo reconoce la dimensión pasiva del derecho a no incriminarse al establecer en su favor la posibilidad de guardar silencio sin consecuencias adversas por su elección. En el mismo cuerpo legal, los artículos 98, 305 y 340, inciso 3 , vienen a establecer el contenido fundamental del mencionado derecho (Wilenmann, 2016: 113). Es importante detenerse en el artículo 305 de este cuerpo normativo, ya que pone de manifiesto el reconocimiento legal explícito de este derecho como principio en relación con la declaración de testigos, permitiéndoles negarse a responder las preguntas que puedan incriminarlos a ellos o a sus parientes.

En la doctrina nacional hay quienes señalan que el derecho a no incriminarse es la vertiente sustantiva del autoencubrimiento. ${ }^{15}$ Sin embargo, creemos que cada una de estas instituciones tiene una naturaleza y fundamento distinto, y que pese a complementarse en algunos elementos de la parte sustantiva, responde uno (derecho a no incriminarse) a principios procesales de garantía de prueba a favor del imputado, explicitando la ausencia de un deber de colaboración con la persecución y el otro (privilegio de autoencubrimiento) a una cuestión estructural de la construcción típica del de las figuras de encubrimiento, que lleva a que las conductas de autofavorecimiento no sean abarcadas por aquellas en razón de la accesoriedad que exige el propio encubrimiento. ${ }^{16}$

\section{El derecho a no incriminarse en la jurisprudencia chilena}

Como veremos, la tendencia de la jurisprudencia chilena suele restringir el derecho a no incriminarse, siendo enfáticos los juzgadores en señalar que este derecho no es absoluto. ${ }^{17}$ Dicha comprensión se sustenta en cómo se configura esta garantía en el ordenamiento chileno. Para dar cuenta de ello, se examinarán a título ejemplar o ilustrativo algunas sentencias sobre este derecho con un criterio de importancia y otro de temporalidad. En primer lugar, se analizarán los fallos más contemporáneos del Tribunal Constitucional..$^{18} \mathrm{La}$ inclinación por el estudio de las sentencias

15. Para más información, véase Wilenmann (2016: 113).

16. Esta accesoriedad se refiere a la necesidad de que el hecho que se encubre se trate de un hecho típico y antijurídico en relación con el cual el injusto típico del cómplice y del encubridor es accesorio con respecto al injusto del autor del hecho principal. En relación con esta cuestión, Gili (1999:76) señala que «el planteamiento de accesoriedad del autofavorecimiento recurriendo a una interpretación análoga del principio rector de la participación, no parece adecuado».

17. Sentencia del Tribunal Constitucional, rol 5952-19; 2381-13; 2936-16; 3948-17; 2897-15.

18. Se realizó una selección de las sentencias en que se invoca la acción de inaplicabilidad por inconstitucionalidad de preceptos legales que vulneran el derecho a no incriminarse desde 2010 en adelante. 
de este tribunal responde a que, desde la reforma a la jurisdicción constitucional del 2005:

El traspaso de la acción de inaplicabilidad al Tribunal Constitucional demostró ser un acierto, ya que este ha sido mucho más proactivo que la Corte Suprema en el tratamiento jurisprudencial de la inaplicabilidad, lo que ha permitido a un número creciente de personas obtener un remedio eficaz a las violaciones de sus derechos (Couso y Coddou, 2010: 390).

\section{Tribunal Constitucional}

A partir de la reforma Constitucional del $2005,{ }^{19}$ la acción de inaplicabilidad por inconstitucionalidad presentada ante el Tribunal Constitucional permite declarar inaplicable - con efecto relativo- el precepto que resulte contrario a la Constitución (García y Contreras, 2013: 230). En la actualidad, sentencias recientes de esta judicatura se han pronunciado sobre el derecho a no incriminarse, previniendo que «toda la perspectiva penal de la materia aún no ha sido íntegramente interpretada por nuestra jurisprudencia en sus casos naturales del ámbito penal». ${ }^{20}$ Con todo, el tribunal ha sostenido importantes lineamientos en relación con su alcance, fundamento y consecuencias.

La sentencia del Tribunal Constitucional del 20 de agosto de 2013, rol 2.381, ya establecía la interpretación restringida del derecho a no incriminarse y daba señales sobre las limitaciones del mismo. En este caso en particular, rechazando la extensión de este derecho a las personas jurídicas y a las causas que no tuvieran naturaleza criminal. ${ }^{21}$ En esta causa, el requirente alega que:

La elección del año de corte responde a que lo que busca este artículo es conocer las tendencias más actuales del tribunal en esta materia desde la incorporación de la acción inaplicabilidad por inconstitucionalidad el 2005, por lo cual nos parece razonable analizar los últimos diez años del desarrollo del derecho a no incriminarse por el Tribunal Constitucional.

19. Para mayor profundidad sobre la acción de inaplicabilidad tras la reforma del 2005, véase Couso y Coddou (2010: 389-430).

20. Sentencia del Tribunal Constitucional del 8 de agosto de 2019, rol 5952-19.

21. Los límites y naturaleza del derecho a no incriminarse se formulan en la sentencia rol 2.381 a propósito de un conflicto relativo a la extensión de este derecho a las personas jurídicas sometidas a la legislación de libre competencia. El tribunal rechaza la inaplicabilidad por inconstitucionalidad que plantea la empresa requirente Ariztía S.A. (acusada por infracción a la libre competencia y vulneración del artículo 3 del Decreto Ley 211, al coludirse y formar un cartel con el objeto de limitar su producción y asignarse cuotas de mercado, en circunstancias que las tres empresas requeridas controlaban más del 92\% de la producción nacional de pollo y más del 93\% de su comercialización en el país) por considerar que el derecho a guardar silencio es solo extensible a las personas naturales y no a las personas jurídicas como reclama el requirente. Estos argumentos serán replicados y complementados en las sentencias posteriores del tribunal en las sentencias de inaplicabilidad en materias de derecho penal. 
1. ${ }^{\circ}$ La aplicación en la gestión pendiente de los preceptos legales impugnados -al obligar al representante legal de Empresas Ariztía a absolver posiciones, bajo juramento- produce precisamente el efecto prohibido por el artículo 19, número 7 , letra f), de la Constitución, afectando en su esencia esta garantía constitucional y, consecuentemente, conculcando también el artículo 19, número 26, de la Carta Fundamental. $2 .^{\circ}$ Se infringe el derecho a la defensa y la garantía constitucional del procedimiento racional y justo, contenidas en el artículo 19, número 3, incisos 1, 2 y 6 , de la Constitución $[\ldots]$ 4. ${ }^{\circ}$ La aplicación de los preceptos legales impugnados en la gestión pendiente, con el resultado de obligar al requirente a declarar bajo juramento sobre hechos propios, en causa de derecho administrativo sancionador, infringe, asimismo, el derecho a defensa y el debido proceso, que incluyen desde luego el derecho a guardar silencio. ${ }^{22}$

El tribunal rechaza la acción, sumando en su libelo las siguientes consideraciones que servirán de base para las posteriores sentencias relacionadas con el derecho a no incriminarse en materia penal:

9. ${ }^{\circ}$ La prohibición constitucional se configura en los casos en que concurren los cuatro supuestos de aplicación: debe tratarse de una causa criminal; debe recaer la obligación en «imputado o acusado»; la obligación ha de consistir en declarar «bajo juramento»; y la declaración debe recaer en «hecho propio». En principio, la ausencia de cualquiera de estos cuatro supuestos en una obligación fijada por la ley impide la aplicación de la prohibición constitucional, a menos que, por motivos calificados, ella sea extensible a situaciones distintas en cumplimiento del mandato del numeral 3 del artículo $19 \mathrm{o}$, bien, ella sea acogida en casos y circunstancias distintas fijadas por la ley en armonía con su deber de establecer las garantías de un procedimiento racional y justo.

Como veremos en los próximos ejemplos, el tribunal establece como requisitos del derecho a no incriminarse los cuatro supuestos contenidos en el artículo 19, número 7 , letra f). Así las cosas, para invocar la prohibición referida tendremos que estar ante una causa criminal, la obligación debe recaer en el imputado o acusado $y^{23}$ la declaración no solo debe ser sobre hecho propio, sino también ser prestada bajo juramento. Sobre estos elementos, en su considerando décimo, el tribunal ha señalado que a propósito del requisito de encontrarnos ante una causa criminal, la «prohibición de autoincriminación beneficia, entonces, a quien encuentra amenaza-

22. Sentencia del Tribunal Constitucional del 20 de agosto de 2013, rol 2.381-13.

23. El considerando décimo noveno señala la imposibilidad de extender la garantía de no incriminación a personas que no son imputados o acusados, para luego agregar - en su considerando vigésimoque las personas jurídicas involucradas en la causa no tienen la calidad de imputadas o acusadas en una causa criminal y desarrollar los argumentos que limitan a las personas jurídicas como titulares de derechos fundamentales, señalando que esto puede ocurrir solo de forma excepcional y restrictivamente. 
da su libertad personal o seguridad individual en el curso de una causa criminal», ${ }^{24}$ pudiendo «extender» esta garantía a causas de otra naturaleza ${ }^{25}$ cuando se vea amenazada en ellas su libertad personal o seguridad individual.

En la misma sentencia, el tribunal señala que los contenidos esenciales de este derecho son dos:

$13 .^{\circ}$ Un sujeto y una acción. El sujeto es un «imputado» o «acusado» beneficiado por el derecho a la libertad personal o seguridad individual. La acción es aquella que puede generar una afectación de la libertad personal o seguridad individual tutelada y que consiste en una declaración sobre un «hecho propio». La ausencia de cualquiera de estos dos elementos impide reconocer la garantía de no autoincriminación. La modificación o adaptación de los supuestos restantes podría ser compatible con la conservación de los elementos que dan identidad a la garantía de no autoincriminación. ${ }^{26}$

Además, agrega que la constatación de estos contenidos esenciales se observa también en los instrumentos de derecho internacional vinculantes con nuestro ordenamiento. ${ }^{27}$

Con posterioridad a esta sentencia, los pronunciamientos del Tribunal Constitucional en materia de derecho a no incriminarse se desarrollarán en sede penal a propósito de la Ley de Tránsito 18.290. La sentencia del 20 de octubre de 2016, rol 2.936, rechazó un requerimiento de inaplicabilidad por inconstitucionalidad con respecto al artículo 195 bis, inciso 1, de esta ley sobre los delitos de conducción en estado de ebriedad con resultado de daños y negativa a la realización de alcoholemia, en que el requirente expresó las posibles vulneraciones al debido proceso y el derecho a no incriminarse ante la situación de ser constreñido a la realización de una prueba —-test de alcoholemia- que puede inculparlo en un ilícito penal. El tribunal argumentó, a propósito de los requisitos señalados en la sentencia rol 2.381, que para que esta garantía sea vulnerada se requiere que el imputado o acusado sea obligado a declarar bajo juramento sobre un hecho propio. ${ }^{28} \mathrm{El}$ tribunal interpretó que esta no es la situación de quien — por mandato legal— está obligado a la realización de una obligación

24. Sentencia del Tribunal Constitucional del 20 de agosto de 2013, rol 2.381- 13.

25. En la misma línea, considerando décimo séptimo, sentencia rol 2.381- 13: La garantía de no autoincriminación tiene aplicación en las causas criminales y podría aplicarse en otros procedimientos jurisdiccionales en tanto los órganos de control de constitucionalidad la consideren parte de la garantía del debido proceso del numeral 3 del artículo 19 constitucional, en los casos y circunstancias en que proceda.

26. Sentencia del Tribunal Constitucional del 20 de agosto de 2013, rol 2381- 13 .

27. Convención americana de derechos humanos y Pacto internacional de derechos civiles y políticos

28. Considerando décimo primero, Sentencia del Tribunal Constitucional del 20 de octubre de 2016, Rol 2936. 
impuesta para proteger el bien jurídico de la seguridad vial, en que además su negativa es una conducta típica sancionada por el legislador:

10. ${ }^{\circ}$ No estamos en presencia de una presunción de culpabilidad, sino de una sanción impuesta a la negativa de cumplimiento de una obligación que se inserta en un tipo penal. En tal caso no aparece vulnerado el artículo 19, número 7, de la Constitución referido a la libertad personal y seguridad individual, ya que es el órgano acusador quien debe probar la ejecución de la conducta punible, de forma tal que no puede existir incompatibilidad con la prohibición constitucional de presumir la responsabilidad penal. En el caso de mérito se trata de una acción — negarse a la práctica de un examen - cuyo incumplimiento tiene como consecuencia o efecto una sanción penal. ${ }^{29}$

Así las cosas, el tribunal interpretó restrictivamente la concurrencia del derecho a no incriminarse, entendiendo que de no encontrarnos ante la situación fáctica de una declaración con los requisitos ya enunciados no se vulnerarían los principios fundantes del debido proceso y del imputado. El tribunal diferencia el derecho a no incriminarse como una garantía procesal y sus posibles vulneraciones con la concurrencia de una conducta descrita en un tipo penal que no afecta las garantías del proceso.

La tendencia del Tribunal Constitucional sobre los requerimientos en materia de la Ley de Tránsito atiende a una interpretación restrictiva que limita este derecho según los requisitos del artículo 19, número 7 , letra f), de la Constitución. ${ }^{30}$ En la misma línea, la sentencia del 4 de julio de 2017, rol 2.897-15, rechazará la acción de inaplicabilidad por inconstitucionalidad de los artículos 195, 196 bis y 196 ter de la Ley de Tránsito. En lo que compete directamente al derecho a no incriminarse, los sentenciadores aclararán en esta oportunidad que no es cierto que exista en el tipo penal un deber de autodenuncia para quien realiza el resultado lesivo, sino que el elemento que exige el tipo penal es dar cuenta o noticia a la autoridad de los hechos acontecidos..$^{31}$ En esta ocasión, el tribunal señalará explícitamente que la concepción chilena del derecho a la no incriminación - a diferencia de lo que ocurre con la Quinta Enmienda en Estados Unidos- es restrictiva, con el único y preciso alcance que le otorga el

29. Sentencia del Tribunal Constitucional del 20 de octubre de 2016, rol 2.936.

30. Al igual que el Tribunal Constitucional, la Corte Suprema ha restringido este derecho en los mismos términos en las causas número 266-2017 y número 35.694-2017.

31. El artículo 195 de la Ley 18.290 señala: «El incumplimiento de la obligación de dar cuenta a la autoridad de todo accidente en que solo se produzcan daños, señalada en el artículo 168, será sancionado con multa de tres a siete unidades tributarias mensuales y con la suspensión de la licencia hasta por un mes. El incumplimiento de la obligación de detener la marcha, prestar la ayuda posible y dar cuenta a la autoridad de todo accidente en que se produzcan lesiones señalada en el artículo 176, se sancionará con la pena de presidio menor en su grado medio, inhabilidad perpetua para conducir vehículos de tracción mecánica y multa de siete a diez unidades tributarias mensuales». 
artículo 19, número 7, letra f) de la Constitución..$^{32}$ Esta sentencia vendrá a limitar la aplicación del derecho a no incriminarse, señalando además que esta garantía:

Opera a partir del primer acto del procedimiento, policial o judicial, dirigido en contra de la persona de quien se atribuye participación en un hecho punible, en condición procesal de imputado (conforme al artículo 7 del Código Procesal Penal), sea o no formalizado, o del acusado, ulteriormente. Por lo que es procesalmente imposible que se oponga tal garantía por y en favor de la misma persona que formula dicha denuncia..$^{33}$

Finalmente, en su considerando trigésimo quinto, el tribunal señalará que este derecho existe dentro de cierto marco, siendo un derecho renunciable, relativo y modulable por el constituyente y el legislador mediante estímulos y sanciones. ${ }^{34}$ Nuevamente, el tribunal establece la diferenciación entre la naturaleza procesal del derecho a no incriminarse y la construcción legal del artículo 195 de la Ley de Tránsito.

De interesante análisis resultan las acciones de inaplicabilidad por inconstitucionalidad rechazadas por el Tribunal Constitucional en causas donde se investigan delitos calificados como violaciones a derechos humanos ocurridos en la dictadura militar. En estas acciones, se suele impugnar un conjunto amplio de artículos del Código de Procedimiento Penal ${ }^{35}$ relativos a declaraciones de testigos, aludiendo a que estos preceptos vulneran el derecho a tutela judicial, debido proceso, presunción de inocencia y derecho a no incriminarse. En estas ocasiones, el tribunal ha profundizado sobre el derecho a no incriminarse, señalando los derechos en los que se fundamenta y el alcance del delito.

En la sentencia del 2 de mayo de 2019, rol 3.948-17, y en la sentencia del 8 de agosto de 2019, rol 5.952-19, el Tribunal Constitucional señala sobre el derecho a no incriminarse que este precepto se «basa en el derecho a defensa y es una de las expresiones de la presunción de inocencia». ${ }^{36}$ Ambas sentencias se pronuncian con respecto al alcance del derecho a no incriminarse, señalando lo siguiente:

Si una persona es imputada de un delito o es investigada bajo esa categoría, esta nueva situación subjetiva la pone de cara a enfrentar esta dificultad. Para ello, habrá momentos de duda o incertidumbre y la actitud pasiva o el silencio pueden representar una etapa de protección derivada de la cautela de quién enfrenta un proceso

32. Véase el considerando trigésimo tercero, sentencia del 4 de julio del 2017, rol 2.897-15.

33. Véase el considerando trigésimo cuarto, sentencia del 4 de julio del 2017, rol 2.897-15.

34. Véase el considerando trigésimo sexto, sentencia del 4 de julio del 2017, rol 2.897-15.

35. Los artículos sobre los cuales se ha presentado acción de inaplicabilidad por inconstitucionalidad en estas causas son: artículo 193, 205, 318, 330, 334, 481, 482 y siguientes del Código de Procedimiento Penal en causas investigadas por los tribunales del crimen.

36. Véase el considerando décimo segundo, sentencia del 2 de mayo del 2019, rol 3.948-17. 
penal. Sin embargo, el derecho a la no autoincriminación no puede identificarse con el silencio, ya que las alternativas que cubre esta garantía abarcan muchos más comportamientos según lo pasamos a describir: i) derecho a guardar silencio; ii) derecho a desarrollar una declaración no autoinculpatoria o derecho a no declarar en contra de sí mismo; iii) derecho a declarar, pero sin la coacción del juramento. Estas modalidades de actuación del imputado pueden tener diversos móviles, ser el resultado de una mera inacción o ser el juicio reflexivo que importa un diseño estratégico de defensa. También hay que tener claro que los procesos penales no son unilaterales y la persecución penal puede modificar estas estrategias, ya que la carga de la prueba reside en quien quiere culpar. ${ }^{37}$

Con esta descripción sobre el alcance del derecho, se verifica que pese a ser un derecho de interpretación restringida, el derecho a no incriminarse es más amplio que el derecho a guardar silencio, ya que el primero se enmarca dentro del derecho a defensa y la presunción de inocencia, como reseña la primera sentencia comentada sobre la cuestión..$^{8}$

Finalmente, los sentenciadores se pronuncian sobre las consecuencias de este derecho, arribando a los siguientes puntos:

Primero, que ni el legislador ni el aplicador del derecho pueden obtener de un modo directo ni indirecto procedimientos, métodos o técnicas conducentes a la obtención de una declaración inculpatoria.

Segundo, que el silencio no es prueba ni confesión autosuficiente de nada.

Tercero, que ningún imputado puede ser condenado sin haber tenido oportunidad de ejercer su derecho a ser oído, en el entendido de desplegar una estrategia de defensa, incluyendo su derecho a guardar silencio, con lo cual es legítimo que un juez solicite una declaración indagatoria.

Cuarto, que rige la máxima de que no debe demostrar su inocencia el imputado.

Quinto, que estas estrategias de defensa pueden ser modificadas, ya que prima el derecho a defensa del imputado, el que puede optar por otras vías más activas, habida cuenta la naturaleza de las pruebas de cargo en su contra en el contexto de la bilateralidad de la audiencia inherente a un proceso penal. ${ }^{39}$

37. Véase el considerando décimo cuarto, sentencia del 2 de mayo del 2019, rol 3.948-17, y considerando décimo sexto, sentencia del 8 de agosto de 2019, rol 5.952-19.

38. Sobre este mismo punto, se entiende que el derecho a guardar silencio, antes de la entrada en vigencia de los principios fundantes del nuevo proceso penal, ya se encontraba garantizado bajo su reconocimiento por el principio de no incriminarse (Pinilla y Vargas, 2005: 23). Al igual que la jurisprudencia revisada, se entiende al derecho a no incriminarse como un principio de mayor amplitud que otras garantías.

39. Véase el considerando décimo quinto, sentencia del 2 de mayo de 2019, rol 3.948-17, y considerando décimo séptimo, sentencia del 8 de agosto de 2019, rol 5.952-19. 
Entre 2018 y 2019, el Tribunal Constitucional ha ido integrando de forma coherente elementos para la delimitación del derecho a no incriminarse, manifestando en cada pronunciamiento la aplicación restringida del mismo y aportando sobre su contenido, alcance, naturaleza y consecuencias. De la revisión de las sentencias invocadas, se puede desprender que para el Tribunal Constitucional el derecho a no incriminarse deberá interpretarse por regla general de forma restrictiva, limitándolo según la expresión del artículo 19, número 7 , letra f).

El criterio de aplicación restringida del derecho a no incriminarse que se extrae de los fallos revisados dice relación con las limitaciones y alcances de este en el caso concreto. Así, uno de los argumentos mas utilizados por el tribunal es la limitación del concepto a la garantía de guardar silencio, la garantía de realizar una declaración no inculpatoria o no declarar contra sí mismo, y el derecho a declarar sin coacción o juramento, garantías que pueden observarse en el artículo 19, número 7 , letra f) (Nogueira, 2007: 152), limitando este principio a lo que estrictamente señala la ley.

\section{La dinámica de los actos posteriores copenados en la legislación chilena}

Los actos copenados son un tema poco atendido por la doctrina y jurisprudencia chilena ${ }^{40}$ las posturas acerca de su naturaleza son diversas y su inserción dogmáticosistémica es un tema debatido (García Albero, 1995: 392) en la mayoría de los ordenamientos jurídicos. Los actos copenados se instauran dentro de la teoría de los concursos, específicamente dentro del estudio del concurso aparente de leyes penales, que reúne los casos excluidos del régimen concursal común (Matus, 2002: 30).

El principio del concurso aparente donde se suele discutir los actos copenados es el de consunción, ${ }^{41}$ señalando Klug que por sí solo ya es un principio complejo, ya que sus definiciones divergen mucho y «en la mayoría de los casos se conduce a una formula muy general y vaga según la cual un tipo legal más amplio excluye a otro» (Klug, 1992: 60).

Para Matus (2002: 33), se debe rechazar el tratamiento concursal común de los actos copenados toda vez que «uno de los preceptos concurrentes regula un hecho que solo puede considerarse como accesorio o meramente acompañante, en sentido amplio, del que regula el precepto principal y desplazante: los actos anteriores, propiamente acompañantes y posteriores copenados». El objeto de análisis jurispru-

40. Se estudian a propósito del concurso aparente de leyes penales y solo lo desarrollan los autores que profundizan sobre materias concursales. Por otra parte, en la jurisprudencia nacional son breves las discusiones sobre su concurrencia.

41. Como señala Etcheberry (1997: 123), el principio de consunción y el principio de especialidad son los que regirán al concurso aparente. Estos dos principios serán aquellos a los que la doctrina mayoritaria reconoce eficacia práctica (Couso y Hernández, 2011: 656). En la misma línea, véase Bustos (1997: 99) y Cury (2005: 668). 
dencial de este artículo estará limitado solo a aquellos donde se discutan los actos posteriores copenados.

Como punto de partida para abordar los actos posteriores copenados, la doctrina española ofrece un comienzo de análisis conceptual al distinguir los actos impunes de los actos copenados. ${ }^{42}$ Distinción que - pese a ser irrelevante en la aplicación práctica- nos permitirá aclarar que el acto posterior copenado no es impune $a$ priori por falta de pena o castigo, sino más bien la valoración de su penalidad será absorbida por el acto anterior, ${ }^{43}$ ya que lo que se absorbe o consume en el delito principal no es la tipicidad del acto, sino más bien su castigo.

Para Roxin, estaremos ante un acto posterior copenado cuando «el hecho posterior solo asegura o aprovecha la posición obtenida por el hecho previo y por ese motivo no requiere una punición autónoma» (Roxin, 2014: 1011). Nos encontramos ante una situación de valoración sobre la punibilidad de un hecho y no sobre la tipicidad del mismo. Roxin (2014: 1014) señala que para encontrarnos ante un acto posterior copenado, deberán concurrir los siguientes requisitos: el acto posterior no puede lesionar un bien jurídico distinto; el acto posterior no puede provocar un nuevo daño; y quien sea perjudicado debe ser el mismo. ${ }^{44}$

En la doctrina chilena, a propósito de la consunción, Etcheberry diseña algunos requisitos para entender la concurrencia de estos actos. En primer lugar, señala que deben existir diversos actos punibles (con indiferencia de si son figuras con «entidad propia o como formas accesorias o imperfectas de otras figuras»). En segundo lugar, indica que los actos concurrentes deben estar relacionados entre sí, ya que esto permitirá «el juicio de valor sobre su relevancia jurídica y determinar su unificación». Finalmente, señala la concurrencia de la «absorción de todos los actos en uno solo de ellos».

A nuestro juicio, consideramos que estamos ante casos en los que existen dos tipos penales diversos con sanción autónoma cada uno de ellos - por ejemplo, homicidio e inhumación ilegal- pero que, por razones de diversa índole, podrán o no ser castigados en conjunto. Por lo tanto, no negamos la posibilidad de que dos hechos puedan ser enjuiciados con una única sanción, escapando de la noción general común de que cuantos delitos se cometan será el número de sanciones que los acompañen. ${ }^{45}$

Parte de la doctrina y sobretodo la jurisprudencia, señalan que el desvalor del delito posterior es subsumible en el desvalor del delito principal. ${ }^{66}$ Para Matus (2002:

42. Para Palma (2004: 15), los actos impunes son los que apuntan hacia la falta de pena o castigo, mientras que los actos posteriores copenados son actos que serán conjuntamente valorados.

43. Sobre esta distinción, véase el ejemplo del robo del mando del garaje (Palma, 2004: 18).

44. En la misma línea, véase Mir (2011: 667).

45. Para más información, véase Mañalich (2016:504) y Maldonado (2016: 563 y ss.).

46. Para más información, véase Etcheberry (1964: 51) y Couso y Hernández (2011: 659 y ss.) con algunas variaciones en relación con la incorporación del principio de insignificancia (Matus, 2002: 30 y ss.). 
33), en estos casos «no estamos ante relaciones lógicas, sino ante valoraciones del sentido de cada una de las normas en juego, ${ }^{47}$ según su forma de realización concreta en los hechos enjuiciados». Estas valoraciones de sentido basadas en la facticidad serán determinantes en la jurisprudencia para considerar la concurrencia en cada caso de una violación al principio ne bis in idem ${ }^{48} \mathrm{y}$, por ende, una solución a través del concurso aparente. ${ }^{49}$ Matus (2002: 35 ) señala que los actos posteriores copenados comprenden el despliegue de conductas de aprovechamiento o destrucción de los efectos del delito en cuya comisión se ha tomado parte, casos de agotamiento de la intención puesta en el delito preferente y actos de autoencubrimiento..$^{50}$

Como prevenimos anteriormente en los actos posteriores copenados, es imprescindible el análisis de la casuística. Para Matus (2002: 34), será en este análisis donde se valorarán cuestiones como cual de los dos preceptos concurrentes será preferente, situación que será analizada según la intensidad relativa que tenga cada uno de ellos, por lo tanto, debe desecharse la consideración en abstracto de que aquel delito que tiene la pena más grave será siempre el principal. El autor propondrá una variante diversa agregando el criterio de la insignificancia..$^{51}$

47. Al respecto, Palma (2004: 94) señala que la estrecha relación entre el acto principal y el acto posterior hacen que el precepto y sanción que corresponde al primero resulte capaz de comprender tanto el contenido desvalorativo propio como el del acto posterior. En la misma línea, véase a García Albero (1995: 386). Para este autor las relaciones no atienden a una concepción lógica, sino más bien a relaciones valorativas de regularidad y normalidad entre ambos delitos. Mañalich (2016: 538) plantea que para la condena de un hecho punible en valoración al reproche de otro, se tendrá que constatar «una determinada relación de proximidad intencional desde el punto de vista de sus respectivos contenidos de significación delictiva». Por su parte, Etcheberry (1964: 51), a propósito del principio de consunción, señalará que este se basa en un «criterio valorativo que decide la absorción de una disposición en otra».

48. Esta garantía prohíbe que un mismo sujeto sea sancionado o perseguido dos veces por un mismo hecho (Mañalich, 2012: 140). Como señala Ossandón, este principio involucra una doble prohibición. En primer lugar, una limitación procesal de doble enjuiciamiento y, en segundo lugar, una prohibición material que impide que un mismo hecho sea valorado dos veces (Mañalich, 2012: 140; Ossandón, 2018: 953).

49. Algunas de las explicaciones que se ofrecen sobre la solución de los actos copenados atiende a la posibilidad de la concurrencia de «un concurso de normas (en Chile concurso aparente); concurso de delitos con la concurrencia de una causa personal de exclusión de la pena; concurso de delitos, pero en que falta la necesidad de la pena con respecto a uno de ellos o concurso de delitos impropio» (Palma, 2004:15).

50. En la misma línea, véase a Couso (2011: 660). En una línea similar, García (1995: 394) señala que los actos posteriores no resultarían más que delitos de aprovechamiento o aseguramiento del ilícito principal.

51. La solución a la que arriba Matus (2002: 31) es que los casos de consunción deberán solucionarse por aplicación del principio de insignificancia. Según el autor, en estos casos la realización de un hecho se presenta como insignificante frente a otro de mayor intensidad criminal y, por lo tanto, es absorbido por este. 


\section{Los actos posteriores copenados en la jurisprudencia chilena}

Como se desarrolló anteriormente, parte de la doctrina analiza los actos posteriores copenados como un concurso aparente de leyes y la jurisprudencia nacional sostuvo esta postura en base a una posible vulneración al principio ne bis in idem..$^{52}$ Sin embargo, la jurisprudencia mas reciente rechaza la concurrencia de un concurso aparente de leyes en determinados casos y busca la solución en otros aspectos como la autonomía del hecho, la afectación a un mismo bien jurídico y la pluralidad de hechos, consideraciones que nos parecen interesantes para explorar propuestas diversas a los concursos.

El análisis de la jurisprudencia sobre los actos posteriores copenados se limitó a un criterio de existencia y de identificación. En primer lugar, se examinaron los casos en que se invocó la existencia de hechos denominados actos posteriores copenados $y$, en segundo lugar, se identificaron los argumentos para considerar si estamos o no ante las siguientes figuras. ${ }^{53}$

\section{Tenencia de artefacto explosivo y daños}

La sentencia del 25 de septiembre de 2013 , rol 4.883, de la Corte Suprema, señala en su considerando vigésimo:

Que los denominados actos posteriores copenados — manifestación de la relación de consunción entre delitos-, genéricamente, son casos en los que la interpretación permite afirmar que la relación existente entre la realización del delito principal y el

52. El principio non bis in idem no tiene un reconocimiento explícito en nuestra Carta Fundamental, sin embargo, se ha ido construyendo por la doctrina y jurisprudencia nacional convirtiéndolo en uno de los principios más recurrentes en materia de sanciones - tanto administrativas como penales- fundando innumerables recursos constitucionales y procesales para su reconocimiento. Dentro de la legislación nacional, este principio deriva de otros reconocidos por la Constitución Política, como el principio de legalidad, tipicidad, seguridad jurídica y proporcionalidad. Siendo este último el que dota de materialidad la necesidad de una sanción proporcional tanto interna como externamente a la establecida en la ley (Gallardo, 2008: 216). Con todo, este principio tiene un reconocimiento implícito a través del inciso segundo de la Constitución Política, que reconoce la vigencia de los tratados internacionales ratificados por Chile, así tendrá reconocimiento supraconstitucional según en el artículo 8.4 de la Convención Americana de Derechos Humanos (Nogueira, 2007: 185). La sentencia de la Corte Interamericana de Derechos Humanos en el caso Almonacid Arellano y otros con Chile del 2006, ya dará cuenta del reconocimiento de este derecho en nuestro ordenamiento, estableciendo a su vez que el mismo no goza de carácter absoluto (2007: 185).

53. Se realizó la búsqueda de sentencias en materia criminal desde el 2000. La muestra se limitó a las sentencias que contuvieran el enunciado de «actos posteriores copenados» toda vez que el análisis de materias como el principio de consunción o concursos aparentes - en que podríamos encontrar discusiones relevantes- sobrepasa la capacidad fáctica de este documento. 
posterior constituye una unidad tal que la ley la considera alcanzada por la pena del primero.

La comentada sentencia desestima que el delito de daños realizado mediante la activación de artefacto explosivo pueda ser considerado como un acto posterior copenado y, por tanto, impune según el tratamiento de la jurisprudencia. Los juzgadores señalan que, en este caso, nos encontramos ante una pluralidad de hechos entendiendo que cada uno de ellos es autónomo e independiente con respecto al otro. El mismo considerando señala que se siguió el criterio rector «que esta detrás de todo concurso aparente de leyes penales, el principio non bis in idem» que se enmarca como una prohibición de doble valoración para evitar que una misma circunstancia o aspecto del hecho tenga relevancia bajo más de una descripción. ${ }^{54}$ Además, la Corte Suprema circunscribe al principio non bis in idem dentro del principio general de proporcionalidad. La línea argumentativa de la Corte para diferenciar ambos hechos atiende a que la tenencia de artefacto explosivo no recoge cabalmente la magnitud del desvalor de los daños eventualmente producidos, señalando que estos delitos de tenencia y daños tienen contenidos de ilicitud independientes y que, de sancionarlos según la lógica de la consunción, se estaría dejando fuera de la sentencia condenatoria el contenido del injusto del delito de daños. ${ }^{55}$

Resulta extraño que los juzgadores excluyeran la concurrencia del artículo 488 del Código Penal - argumentada por la defensa - únicamente aludiendo a la inexistencia de unidad de hechos por considerar que no hay relación entre ambos delitos (tenencia de artefacto explosivo y daños) ni desde un punto de vista valorativo ni espacio-temporal. Sin embargo, la disposición del artículo en comento es una regla de privilegio toda vez que se castigará solo cuando el hecho no pueda considerarse constitutivo de otro delito que merezca mayor pena (Matus, 2002: 33), lo que en la especie podría haber ocurrido. Como señala Matus, al faltar fundamento lógico de la relación entre estos preceptos, se estará a consideraciones valorativas de carácter empírico como ocurre en la sentencia comentada, en que finalmente la Corte valorará el costo monetario de los daños producidos otorgándole un estándar de importancia significativa a esta cuantía y además a la relación espacio-temporal de los hechos para desestimar su ocurrencia.

\section{Tráfico de drogas y lavado de activos}

La sentencia de la Corte de Apelaciones de San Miguel del 7 de septiembre de 2011, rol 993, nos parece una de las argumentaciones más coherentes de la jurisprudencia

54. Considerando vigésimo, sentencia de la Corte Suprema del 25 de septiembre de 2013, rol 4.883.

55. La solución que entrega la Corte en este caso a propósito de la existencia de pluralidad de hechos es la del concurso medial del artículo 75 del Código Penal. 
para desestimar la concurrencia de un acto posterior copenado en el caso del lavado de activos. Esta sentencia señala que, al existir afectación de bienes jurídicos diferentes, no se abarcará en todos los casos de forma íntegra el desvalor del blanqueo posterior. La Corte funda su argumento señalando que es de lato conocimiento que ambos delitos son autónomos e independientes el uno del otro, y que además los bienes jurídicos afectados son diversos, afectando el delito de lavado de activos a la administración de justicia o el orden socioeconómico. ${ }^{56}$ La Corte señala que al afectarse bienes jurídicos diferentes «el desvalor del hecho previo - tráfico- no abarca en todos los casos la integridad del desvalor del posterior blanqueo», lo que sin duda es un argumento propio del análisis de un concurso aparente.

El recurso de nulidad de la defensa argumentó que el lavado de activos puede constituirse como el agotamiento del delito de tráfico de drogas y que, siendo así, existiría una vulneración al principio ne bis in idem «debido a que la obtención de recursos económicos mediante la comisión de este delito y su posterior aprovechamiento debe valorarse como inherente al mismo hecho punible». ${ }^{77} \mathrm{El}$ argumento de la Corte señala la necesaria concurrencia de pluralidad con respecto a la cual constata la afectación de bienes jurídicos diversos.

Los sucesivos temas encontrados a propósito de los actos posteriores copenados versan sobre el caso de un homicidio calificado y, por otro, un femicidio, ${ }^{58}$ ambos con posterior ocultamiento del cuerpo. Además, se presenta el caso del delito de robo, receptación e incendio. En esta ocasión se advierte una variante distinta de análisis: la existencia de una valoración de autoencubrimiento, que es lo que nos compete para analizar toda vez que es en estos casos donde encontraremos argumentaciones relacionadas con el derecho a no incriminarse.

56. Considerando décimo quinto de la sentencia de la Corte de Apelaciones de San Miguel del 7 de septiembre de 2011, rol 993: «Que para los efectos de analizar la infracción de derecho a que se alude útil resulta destacar que el delito de lavado de activos, tanto en el derecho comparado como en nuestra propia legislación es considerado un delito autónomo, independiente del delito precedente, y así el artículo 27 de la Ley 19.913 dispone quien «de cualquier forma oculte o disimule el origen ilícito de determinados bienes, a sabiendas de que provienen directa o indirectamente, de la perpetración». En consecuencia, si se valora que el bien jurídico protegido por el lavado de activos es la Administración de Justicia o el orden socioeconómico, vemos que el desvalor del hecho previo no abarca en todos los casos la integridad del desvalor del posterior blanqueo, hay una afectación de bienes jurídicos diferentes».

57. Considerando décimo sexto de la sentencia de la Corte de Apelaciones de San Miguel del 7 de septiembre de 2011, rol 993.

58. Sentencia de la Corte de Apelaciones de Punta Arenas del 2 de febrero de 2015, rol 183-2014. 


\section{Homicidio-femicidio e inhumación ilegal}

En la sentencia de la Corte Suprema del 17 de octubre de 2012, rol 5.833, la defensa alega violación al principio ne bis in idem por considerar que la inhumación constituye un acto posterior copenado que busca - en este caso- el ocultamiento posterior del delito principal, «por lo que solo resulta explicable como un modo de aseguramiento de la impunidad del homicidio», ${ }^{59}$ señalando que, por lo tanto, nos encontramos ante un caso de concurso aparente de leyes penales.

En el considerando vigésimo, la Corte señala:

Como se advierte de la simple descripción del hecho punible que tuvo por cierto el tribunal, el intento de quemar el cuerpo de la niña y el haberlo enterrado fueron hechos con la finalidad de ocultar su crimen y las evidencias que el cuerpo presentaba. No hay duda de que estos actos posteriores al homicidio de la niña tuvieron por único objetivo el ocultamiento de un delito propio y, como tales, están consumidos por el homicidio al que acceden y a cuyo encubrimiento apuntaban. En este sentido, existe efectivamente una violación al principio del non bis in idem, puesto que una conducta única se está sancionando dos veces por la vía de calificar un mismo hecho como dos injustos diversos. ${ }^{60}$

La Corte desestima el desvalor propio del delito autónomo de la inhumación, sindicándolo con una actividad de ocultamiento posterior que buscaba el aseguramiento de su impunidad (autoencubrimiento). ${ }^{61}$ Ahora bien, en 2015, la sentencia sobre femicidio e inhumación posterior de la Corte de Apelaciones de Santiago desestima - a diferencia del caso anterior- las invocaciones de la defensa sobre la concurrencia de la inhumación como acto posterior copenado o autoencubrimiento impune.

La Corte advierte que el razonamiento de la defensa es incoherente al fundar su alegación de impunidad de la inhumación por considerar esta figura dentro de la hipótesis del artículo 17, número 2, del Código Penal. Además de adherir a esta lógica, consideramos que el razonamiento de la defensa yerra al señalar que la impunidad del autoencubrimiento y del acto posterior copenado sea tal a todo evento. Según estas apreciaciones, la Corte rechaza el recurso en su considerando duodécimo aten-

59. Sentencia de la Corte Suprema del 17 de octubre de 2012, rol 5.833.

6o. Sentencia de la Corte Suprema del 17 de octubre de 2012, rol 5.833 .

61. En la misma línea, la sentencia de la Corte de Apelaciones de Punta Arenas del 3 de marzo de 2011, rit 4-2011, acoge el recurso de nulidad presentado por la defensa, señalando que en la causa de homicidio, la posterior quema del vehículo no constituye el delito de incendio en atención a que la motivación de quemarlo era el ocultamiento de evidencias que pudieran inculparlo en el delito principal. La Corte, además de esgrimir consideraciones en cuanto a la concurrencia del tipo subjetivo del delito de incendio, adhiere al considerando sobre los argumentos de Matus, sobre el desplazamiento del delito de incendio por el de homicidio, siendo posible solo considerar al primero como un delito posterior accesorio y acompañante. 
diendo a que lo sostenido por la defensa «no se enmarca en los planteamientos de la referida institución, ni asimilables a la jurisprudencia de esta Corte». ${ }^{62}$

\section{Robo calificado, receptación e incendio}

La jurisprudencia más reciente que abordó los actos posteriores copenados fue conteste en rechazar la existencia de un concurso aparente y desestimar la concurrencia de la figura del autoencubrimiento. El pronunciamiento de la Corte de Apelaciones de San Miguel de $2016^{63}$ condenó por robo calificado, receptación e incendio para el autor, con cumplimiento efectivo de todas las penas.

En este caso, la defensa razonó nuevamente en torno a que el incendio era una figura de autoencubrimiento señalando:

Que la tercera circunstancia que se denuncia como fundamento de la causal invocada se refiere al delito de incendio, estimando errónea la aplicación del artículo 477, número 1, del Código Penal al hecho, por configurarse al parecer del recurrente la hipótesis contemplada en el artículo 17, número 2, del Código Penal. En efecto, sostiene, se trata de una figura de «autoencubrimiento», lo que no fue considerado por los sentenciadores que encuadraron el hecho en la figura típica del incendio, pese a existir una causal de exculpación. Explica que el autoencubrimiento es aquel en virtud del cual todas aquellas acciones dirigidas a borrar evidencias de un hecho principal ilícito se estiman subsumidas dentro de la dañosidad propia del primer delito, ya que no manifiesta una nueva o distinta peligrosidad del sujeto activo, entendiéndose que se trata de una conducta natural y obvia de toda persona que se ha visto envuelta en ilícitos y debe resultar impune por cuanto se identifica con el agotamiento del delito. ${ }^{64}$

La Corte señala que no hay disposición legal sobre el autoencubrimiento como causal de exculpación, por lo cual estima que no puede ser infringida o erróneamente aplicada una causal inexistente en nuestro ordenamiento jurídico. En este caso, la Corte exhibe la dificultad de basar alegaciones sobre una errada relación entre el encubrimiento del artículo 17 del Código Penal y la figura del autoencubrimiento que, por deducción lógica, no puede ser invocado en el caso en comento, por cuanto es el autor del delito principal quien realiza los hechos y no puede considerarse - por expresa disposición legal contenida en ese tipo-como encubridor del mismo delito.

62. Sentencia de la Corte de Apelaciones de Punta Arenas del 2 de febrero de 2015, rol 183-2014.

63. Sentencia de la Corte de Apelaciones de San Miguel del 18 de marzo de 2016, rol 240.

64. Sentencia de la Corte de Apelaciones de San Miguel del 18 de marzo de 2016, rol 240. 


\section{Principales nudos críticos para posibles soluciones}

De las sentencias comentadas, podemos desprender que son oscuros los pasajes de solución por parte de la jurisprudencia con respecto a los actos posteriores copenados. No hay criterios de unidad en sus resoluciones y las vías de solución entremezclan contenido de diversas instituciones.

Entre los medios de solución comunes observados en las sentencias, en primer lugar se encuentra la existencia de un concurso aparente de leyes penales (casos de consunción) y, en segundo lugar, un reconocimiento de estos actos como figura de autoencubrimiento impune. De estas soluciones se desprenden consecuencias prácticas importantes en lo que respecta a la determinación efectiva de la pena, ya que en cualquiera de estos dos supuestos el autor responderá solo por el delito principal, con exclusión del acto posterior.

Sin embargo, en los razonamientos de los tribunales de los últimos cinco años, encontramos tendencias que se orientan a señalar que en los casos estudiados estaríamos ante un auténtico concurso de leyes ${ }^{65}$ por no existir una unidad de hechos, de lo que podemos desprender que si optamos por esta vía, la pena asignada a los hechos será mayor que en los casos del párrafo anterior por concurrir según el caso concreto, un concurso medial ${ }^{66} \mathrm{o}$ concurso real. ${ }^{67}$

El razonamiento de la jurisprudencia más reciente se orienta hacia la existencia de un auténtico concurso de delitos, que relaciona aspectos de concurrencia de desvalor efectiva del hecho posterior al hecho principal y cuestiones sobre la afectación de bienes jurídicos distintos y la autonomía de la figura típica. Nos parece un acierto la solución de recurrir a figuras generales del derecho penal como la afectación de un bien jurídico y la autonomía del delito. Además, consideramos que sería orientador agregar algunos razonamientos en consideración a la temporalidad de ocurrencia que vincula a ambos hechos y la constatación en el caso concreto de la pluralidad de hechos.

Al reconocer la autonomía en sentido estricto de estos delitos y la afectación de un bien jurídico distinto, ${ }^{68}$ se rechaza el concurso aparente de leyes como solución. De esta forma, las orientaciones mas recientes de la jurisprudencia trasladan el escenario a la existencia de un concurso efectivo de leyes, cualquiera sea su forma (real, medial o ideal).

En cuanto a la autonomía, como regla general orientadora, consideramos relevante saber cuándo estamos ante un delito autónomo. Etcheberry (1964: 53), ya en

65. En relación con la diferenciación sobre un auténtico concurso de leyes y uno aparente, véase Maldonado (2007: 207 y ss.), Mañalich (2016: 506), y Artaza, Mendoza y Rojas (2019: 150).

66. Sentencia del 25 de septiembre de 2013, rol 4.883, de la Corte Suprema.

67. Sentencia de la Corte de Apelaciones de San Miguel del 18 de marzo de 2016, rol 240.

68. Sobre la importancia de la concurrencia de afectación de uno o más bienes jurídicos, véase a modo ejemplar García Pérez (2008: 154). 
su tesis magistral, señala que los delitos autónomos serán aquellos que conserven su propio valor delictivo y reciban la penalidad correspondiente por separado. Posteriormente, agrega que los delitos no autónomos serán aquellos que dependan de un hecho principal y relaciona esta idea con «la regularidad de aparición de aquellos en relación con el delito principal al cual sirven o se subordinan» (Etcheberry, 1997: 127).

Entonces, cabe preguntarnos: ¿tiene el tipo penal de inhumación un desvalor y penalidad propio cuando no concurre un delito anterior? Si lo anterior es efectivo, entonces la presencia de esta figura autónoma permite descartar los efectos del concurso aparente por la vía de la consunción y correlativamente se descartan las consecuencias que se asignan al agotamiento delictivo. En el mismo ejemplo, ¿podríamos afirmar que el delito de homicidio incluye el desvalor de todos los posibles actos posteriores en su comisión? Parece ser - según la descripción típica del hecho-que no es posible arribar a esta conclusión, menos si se considera que los actos se ejecutaron en un contexto espacial temporal que no era relevante para efectos de entender que se cumplieron los elementos del tipo (consumación). ${ }^{69}$

La existencia de tipos penales por decisión del legislador - como la inhumación, la receptación o el lavado de activos- no es baladí, ya que responde a la suficiencia de protección de nuestros bienes jurídicos más preciados, que según un análisis de política criminal (que debería ser serio y proporcional) se van integrando a nuestro ordenamiento jurídico precisamente para ser castigados.

Otra regla general orientadora que permitiría complementar estas soluciones alternativas es la afectación de bienes jurídicos distintos. Este criterio que se ha desarrollado por la jurisprudencia viene a identificar si en el caso concreto estamos ante una afectación múltiple de bienes jurídicos. En su mayoría, la jurisprudencia nacional tenderá a considerar que, en los casos de lavado de activos, inhumación y receptación, las dos reglas anteriores serán útiles para estimar estos hechos como autónomos y no como actos posteriores copenados..$^{\circ}$

Un segundo nudo crítico en la jurisprudencia ${ }^{71}$ lo abordamos a propósito de la

69. García Albero (1995: 177) señala que la doctrina mayoritaria en España —al igual que la doctrina chilena - prescinde de las relaciones lógicas entre preceptos para entender la impunidad del acto posterior. Por el contrario, adscriben a la relación de una unidad valorativa. En esta línea, se entendería que el tipo principal ya contendría explícitamente el desvalor representado por el acto posterior. Sin embargo, hay otros autores que recurren a la solución basándola en relaciones lógicas, lo que en la práctica imposibilita la concurrencia de un concurso aparente. Para más información, véase la tesis de Klug (1995: 151).

70. Nuestra jurisprudencia yerra al considerar que la sola afectación de bienes jurídicos distintos es suficiente para descartar la presencia de actos posteriores copenados. «La copunición de un hecho posterior no es solo una cuestión de comparación de bienes jurídicos, como parece desprenderse de la exigencia de que no se produzca un incremento en el daño» (Palma, 2004: 146).

71. Como ejemplo más actualizado, véase la sentencia de la Corte de Apelaciones de San Miguel del 18 de marzo de 2016, rol 240. 
inexistencia de disposición legal sobre el autoencubrimiento como causal de exculpación y, por lo tanto, la imposibilidad de alegarla como causal de impunidad en un proceso penal, como ocurrió en la última sentencia comentada. Una vía alternativa para el razonamiento de la Corte en dicho caso sería plantear la impunidad del acto por cuestiones relativas al derecho a no incriminarse a través de la creación de una figura de autoencubrimiento, y así desplazar la idea del autoencubrimiento como una forma de participación accesoria del delito principal. ${ }^{72}$

El tratamiento del encubrimiento se encuentra en el artículo 17 del Código Penal como forma de participación, sin perjuicio de que la doctrina nacional niegue que esta figura sea realmente una forma de participación, considerando que el delito ya se realizó íntegramente y que afectaría un bien jurídico distinto del afectado por el delito que se encubre (Couso y Hernández, 2011: 418). Según el inciso primero, estas conductas pueden ser realizadas «solo por los encubridores», restando de esta posibilidad al autor y cómplice del delito..$^{73}$ Bajo esta hipótesis, no es posible que el autor del delito encubierto tenga participación en él mismo como encubridor. Sin embargo, el legislador ha instalado diversas hipótesis autónomas (fuera del precepto del artículo 17 del Código Penal y sancionadas en la parte especial) en las que, por esta vía, el autor de un delito además podrá ser castigado por el delito posterior que lo favorece o le permite encubrirlo (por ejemplo: inhumación, lavado de activos, receptación).

Así las cosas, cabe preguntarnos qué sucede con el autor del delito principal que realiza otro hecho para encubrir el primero. Esta figura es el autoencubrimiento, que como señaló la Corte, no tiene una causal general existente en el ordenamiento jurídico. ${ }^{74}$ Es preciso señalar que nada tienen que ver las causales del encubrimiento del artículo 17 con la situación de quien busca encubrir o favorecerse de «su propio delito anterior», ya que el autofavorecimiento es atípico (Gili, 1999: 91). La confusión de lege lata ocurre debido a que ambas figuras - especie - se fundamentan en un principio - género- antecesor, que es el derecho a no incriminarse desde una perspectiva de este derecho amplio, que se extiende en el caso del encubrimiento a la intención de «no incriminar»o «perjudicar» a un tercero, y en el caso del autoencubrimiento a la intención de «no autoincriminarse» $\mathrm{o}$ «perjudicarse» por hechos propios.

La razón de la impunidad del autoencubrimiento no puede ser considerada únicamente como un caso de aplicación del derecho a no autoincriminarse del cual constituiría su manifestación sustantiva. En algunas soluciones de la Corte, se advierte la existencia de elementos que fundamentan la impunidad del autoencubrimiento

72. Sobre algunas consideraciones del encubrimiento como forma de participación y sus teorías, véase Verde (2019: 76 y ss.).

73. El artículo 17 del Código Penal señala que serán encubridores quienes no hayan participado en el delito como autores ni cómplices y que intervengan con posterioridad a su ejecución.

74. Sentencia de la Corte de Apelaciones de San Miguel del 18 de marzo de 2016, rol 240. 
desde una consideración amplia del derecho a no autoincriminarse ${ }^{75}$ al reconocer la aceptabilidad del despliegue de acciones - que pueden ser constitutivas de delito o no- para no incriminarse. Esta manifestación da cuenta de la relación que fundamenta la figura del encubrimiento y además del autoencubrimiento, sin embargo, no puede aplicarse como principio para soluciones jurídico-penales toda vez que este derecho sirve para entender el fundamento procesal (Gili, 1999: 85) que hay detrás -que por lo demás es limitado- y no para analizar los elementos del tipo en estos casos.

El fundamento que se alude para entender la relación entre el autoencubrimiento y el derecho a no incriminarse tiene relación con la regla general contenida en el aforismo nemo tenetur se detergere (Gili, 1999: 85). Como ya vimos en el desarrollo del derecho a no incriminarse, para la mayoría de la doctrina comparada y las normas internacionales este aforismo implica el derecho de una persona para no declarar contra sí mismo y no confesarse culpable (Gili, 1999: 85). Esta regla general dotará de argumentaciones de carácter procesal, político criminal, sistémico, atinentes a la naturaleza propia del ser humano ${ }^{76} \mathrm{y}$ de inexigibilidad, hacia sostener la impunidad del autoencubrimiento (Gili, 1999: 85).

Gili señala que estos argumentos - a propósito de la doctrina y jurisprudencia mayoritaria española - apuntan al principio natural de autoconservación; de inexigibilidad de una conducta que justificaría esta situación de no declarar en contra o perjudicarse; de ineficacia y falta de sentido de la que adolecería la autoincriminación y por la falta de regla expresa que tipifique las conductas de autoencubrimiento (Gili, 1999: 82 y ss.).

\section{Conclusión}

Este artículo pretendía poner de manifiesto las tendencias de la jurisprudencia sobre el derecho a no incriminarse y los actos posteriores copenados, analizando la correspondencia entre ambas instituciones. De este ejercicio práctico se desprenden algunas conclusiones generales para orientar un estudio más profundo de cada caso:

- El tratamiento jurisprudencial del derecho a no incriminarse era heterogéneo hasta la concurrencia de la acción de inaplicabilidad por inconstitucionalidad.

75. La valoración absoluta o amplia del derecho a no incriminarse como garantía procesal podría utilizarse como argumento en estos casos, con la salvedad de que es conocido que la interpretación de este derecho es bastante restringida y limitada a los requisitos del artículo 19, número 7 , letra f), como bien se desarrolló al inicio de este documento. El fundamento tras la idea de la impunidad del autoencubrimiento podría ser valorado en estos casos por el derecho a no incriminarse en sentido amplio. En relación con esto, véase Gili (1999: 85).

76. Como manifestación de autopreservación, véase González (2013: 100). 
El Tribunal Constitucional ha tendido mayormente a interpretar este derecho de forma restrictiva, negando la inconstitucionalidad de preceptos en materia penal como el artículo 195, 196 bis y 196 ter de la Ley de Tránsito.

- No existen criterios uniformes en la jurisprudencia chilena al tratar los actos posteriores copenados. Sin embargo, en las sentencias de los últimos años en estudio, la tendencia se inclina a rechazar la concurrencia de un concurso aparente de leyes penales y, por el contrario, soluciona esta problemática a través del concurso real o medial observando cierta autonomía de las figuras recurridas y una afectación múltiple de bienes jurídicos, para concluir la existencia de una pluralidad de hechos.

- A propósito de las figuras de lavado e inhumación, pueden reconocerse tipos de la parte especial que permiten castigar al autor del delito que los precedió. En este sentido, constituyen tipos penales independientes con respecto a este último, donde sus posibles autores pueden ser el mismo sujeto que llevó a cabo el delito precedente o bien un tercero, por lo que ante la existencia de tipos autónomos como los revisados en el presente documento parece aceptable orientar su solución hacia el reconocimiento de un auténtico concurso de leyes.

- La confusión existente entre la figura del encubrimiento del artículo 17 del Código Penal y el autoencubrimiento tiene su origen en admitir que dicho precepto incluye las conductas realizadas por el autor del delito que se quiere encubrir, hecho que por razones de lege lata no es posible, ya que la descripción típica del artículo en comento excluye al autor de las hipótesis del artículo 17.

- El derecho a no incriminarse - mirado desde una perspectiva amplia- fundamenta la idea de «no incriminarse» 0 «perjudicarse» que se observa en la intención de encubrir ciertos actos que realiza tanto el autor del delito como el encubridor. A nuestro parecer, el límite de este fundamento se manifiesta —en el encubrimiento del artículo 17-cuando quien realiza esta conducta, además se favorece con su acción, mientras que en el caso del autofavorecimiento el límite de este derecho se observará cuando la realización del acto posterior implique una afectación mayor no contenida dentro de la figura principal y cuando este acto signifique un aprovechamiento para el autor del hecho precedente.

\section{Referencias}

Andrés, Perfecto (2020). «En materia de prueba: sobre algunos cuestionables tópicos jurisprudenciales». Revista Internacional sobre Razonamiento Probatorio, 1: 75-102. Disponible en bit.ly/2MowOkQ. 
Artaza, Osvaldo, Ricardo Mendoza y Luciano Rojas (2019). «La consunción como regla de preferencia en el marco del concurso aparente de leyes». Revista de Derecho de la Pontificia Universidad Católica de Valparaíso, 53: 147-176. Disponible en bit.ly/2U4inHo.

Bilalli-Zendeli, Arta (2015). "Privilege against Self-Incrimination-Guarantee for Fair Trial in Modern Criminal Procedures (Nemo Tenetur Prodere Seipsum)”. Revista de Stiinte Politice, 47: 155-164. Disponible en bit.ly/2XUZYod.

Bustos, Juan y Hernán Hormazábal (1997). Lecciones de Derecho Penal. Tomo I. Madrid: Trotta.

Castillo, Ignacio (2012). «El derecho a no autoincriminarse y las advertencias de «miranda»: Un nuevo retroceso de la Corte Suprema de los Estados Unidos. Comentario a la sentencia de la Corte Suprema de los Estados Unidos, en el caso Howes v. Fields, del 21 febrero de 2012». Ius et Praxis, 18 (2): 427: 437. Disponible en bit.ly/zeNswzP.

Correa, Carlos (2018). «Valoración del silencio del imputado en el proceso penal. Derecho alemán y derecho chileno». Revista de Derecho Valdivia, 31 (2): 237-261. Disponible en bit.ly/3gPGnHt.

Couso Jaime y Alberto Coddou (2010). «LA NATURAleza JuRídica de la aCción DE INAPLiCABILIDAd EN LA JURISPRUdencia del Tribunal Constitucional: Un desafío Pendiente». Revista de Estudios Constitucionales, 8 (2): 389430. Disponible en bit.ly/301ZQPa.

Couso, Jaime y Hernández, Héctor (2011). Código Penal Comentado. Parte general, doctrina y jurisprudencia. Santiago: Abeledo Perrot.

Cury, Enrique (2005). Derecho Penal: Parte general. Santiago: Universidad Católica de Chile.

ETCHEBERRY, Alfredo (1964). El concurso aparente de leyes penales. Santiago: Jurídica de Chile.

-. (1997). Derecho Penal. Parte General II. Santiago: Jurídica de Chile.

Epstein, Richard. (2015). "Entick v Carrington and Boyd v United States: Keeping the Fourth and Fifth Amendments on Track". The University of Chicago Law Review, 82 (1): 27-50. Disponible en bit.ly/3eJZSQ6.

Gallardo, María (2008). Los principios de la potestad sancionadora. Teoría y práctica. Madrid: Iustel.

García Albero, Ramón. (1995). Non bis in idem material y concurso de leyes penales. Barcelona: Cadecs.

García, Gonzalo y Pablo Contreras (2013). «El derecho a la tutela judicial y al debido proceso en la jurisprudencia del Tribunal Constitucional chileno». Revista de Estudios Constitucionales, 11 (2): 229-282. Disponible en bit.ly/3drEHSH.

García Pérez, Octavio (2008) El encubrimiento y su problemática en Código Penal. Barcelona: Atelier. 
GiLI, Antoni (1999). En encubrimiento en el Código Penal de 1995. Valencia: Tirant lo blanch.

Gonzalez, María (2013). La carga dinámica de la prueba y sus límites. Santiago: Thomson Reuters.

GraY, Anthony (2013). "The Right to Silence: Using American and European Law to Protect a Fundamental Right”. New Criminal Law Review: An International and Interdisciplinary Journal, 16 (4): 527-567. Disponible en bit.ly/2XVmVAE.

HernánDEZ, Héctor (2015). «¿Derecho de las personas jurídicas a no auto- incriminarse?» Revista de Derecho de la Pontificia Universidad Católica de Valparaíso 44: 217-263. Disponible en bit.ly/3duJKly.

Horvitz, María Inés y Julián Lopez (2004). Derecho procesal penal chileno. Tomo II. Santiago: Jurídica de Chile.

Jane, Philippa (2010). The privilege against Self-incrimination. Nemo Tenetur Prodere Seipsum: Misinterpreted and Misapplied. Saarbrücken: Lambert Academic Publishing.

KLUG, Ulrich (1992). Problemas de la filosofía y de la pragmática del derecho. $1 .^{\mathrm{a}} \mathrm{ed}$. México: Fontamara.

Lefebvre, Francis (2019). Memento práctico. Procesal Penal. Madrid: Lefebvre.

Maldonado, Francisco (2007). «Delito continuado y concurso de delitos». Revista de Derecho Valdivia, 28 (2): 193-226. Disponible en bit.ly/3drpLUB.

MaÑALICH, Juan Pablo (2012). «El principio ne bis in idem en el derecho penal chileno». Revista de Estudios de la justicia, 15: 139-169. Disponible en bit.ly/2TZEmic.

MaÑalich, Juan Pablo (2016). «El concurso aparente como herramienta de cuantificación penológica de hechos punibles». En Claudia Cárdenas y Jorge Ferdman (coordinadores), El derecho penal como teoría y como práctica: libro en homenaje a Alfredo Etcheberry Orthusteguy (pp. 501-547). Santiago: Legal Publishing.

Matus, Jean Pierre (2002). «La teoría del concurso aparente de leyes penales y el «resurgimiento» de la ley en principio desplazada». Revista de Derecho, 9: 27-68. Disponible en bit.ly/2Bmi8zn.

Mir Puig, Santiago (2011). Derecho Penal: Parte General. 9. ${ }^{a}$ ed. Barcelona: Reppertor.

Nogueira, Humberto (2007). El debido proceso en la Constitución y el sistema Interamericano. Santiago: Librotecnia.

Ossandón, María Magdalena (2018). «El legislador y el principio ne bis idem». Política Criminal, 13 (26): 952-1002. Disponible en bit.ly/36SVfAg.

Ormazábal, Guillermo (2015). El derecho a no incriminarse. Navarra: Thompson Reuters.

Palma, José. (2004). Los actos copenados. Madrid: Dykinson S.L.

PÉreZ, Javier y Manuel Carrasco (2018). Curso de derecho constitucional. Madrid: Marcial Pons. 
Pinilla, Rocío y Alejandro Vargas (2005). El derecho a guardar silencio en el nuevo proceso penal. Santiago: Jurídica Congreso Ltda.

Roxin, Claus (2008). La prohibición de autoincriminación y de las escuchas domiciliarias. Buenos Aires: Hammurabi.

Roxin, Claus (2014). Derecho Penal. Parte General. Tomo II. Madrid: Civitas - Thomson Reuters.

Stein, Alex (2011). "Self- Incrimination". En Encyclopedia of Law and Economics. Tomo X (pp. 366-385). Cheltenham: Edward Elgar Publishing Limited. Disponible en https://bit.ly/2Vx36PE

Trechsel, Stefan (2005). Human Rights in Criminal Proceedings. Nueva York: Oxford University Press Inc.

VAlenzuela, Jonatan (2015). Omisión de dar cuenta a la autoridad policial y negativa injustificada a someterse a examenes corporales desde una perpectiva constitucional y procesal. Informe en Derecho, Departamento de Estudios Defensoría Penal Pública. Disponible en https://bit.ly/2BPMcVq

Verde, Alejandra (2019). La Receptación como delito contra el mercado formal. Delimitación con el encubrimiento. Delito posterior copenado. Madrid: Marcial Pons.

WilenManN, Javier (2016). «El tratamiento del autofavorecimiento del imputado. Sobre las consecuencias sustantivas del principio de no autoincriminación». Revista de derecho, 3 (1): 111-139. Disponible en bit.ly/2BmGJVL.

\section{Agradecimientos}

Este artículo fue desarrollado en el marco del proyecto de investigación Fondecyt regular 1170276 titulado "Concurso de delitos como concurrencia de leyes penales», cuyo investigador responsable es Francisco Maldonado Fuentes.

\section{Sobre la autora}

Gloria Mancilla Ibacache es abogada investigadora del Centro de Estudios de Derecho Penal de la Universidad de Talca. Su correo electrónico es gloria.mancilla. ibacache@gmail.com. 
La Revista de Estudios de la Justicia es publicada, desde 2002, dos veces al año por el Centro de Estudios de la Justicia de la Facultad de Derecho de la Universidad de Chile. Su propósito es contribuir a enriquecer el debate jurídico en el plano teórico y empírico, poniendo a disposición de la comunidad científica el trabajo desarrollado tanto por los académicos de nuestra Facultad como de otras casas de estudio nacionales y extranjeras.

\author{
DIRECTOR \\ Álvaro Castro \\ (acastro@derecho.uchile.cl) \\ SITIO WEB \\ rej.uchile.cl \\ CORREO ELECTRÓNICO \\ cej@derecho.uchile.cl \\ LICENCIA DE ESTE ARTÍCULO \\ Creative Commons Atribución Compartir Igual 4.o Internacional
}

La edición de textos, el diseño editorial

y la conversión a formatos electrónicos de este artículo

estuvieron a cargo de Tipográfica

(www.tipografica.io). 